\section{Several HLA Haplotypic Factors for Both Type 1 (Insulin-Dependent) and Type 2 (Non-Insulin-Dependent) Diabetes}

Sir,

HLA-B 15, B 8 and B 18 are associated with Type 1 (insulin-dependent) diabetes susceptibility gene(s) [1]. These associations are secondary to a stronger DR 3 and DR4 association [2]. BfF1 has also been reported to be increased in Type 1 diabetes [3, 4]. Different HLA markers may be linked to Type 1 diabetes susceptibility in different populations: DRw 8 in Japanese [5], B18 in Southern Europeans [6]. Moreover, BfF1 is peculiarly increased in the normal Spanish population [7]. On the other hand, Type 2 (non-insulin-dependent) diabetes has not been found to be associated with HLA factors except perhaps in a few cases [8]. We have mapped susceptibility genes within the HLA region in a sample of Spanish diabetic patients using available HLA markers.

Ninety-seven Type 1 and 113 Type 2 patients were typed for HLA-A, B, C and DR $[9,10]$ and 61 Type 1 and 101 Type 2 diabetic patients were also typed for $\mathrm{Bf}$ [11]. Criteria for classification were those established by the National Diabetes Data Group [12]. HLA and $\mathrm{Bf}$ frequencies found in the patients were compared with those found in normal subjects $[7,11]$. The $p$ values given are with Yates' correction and multiplied by the number of tested antigens when more than 20 were considered.

In the Type 1 patients we found that: (a) B 8 (16.5\%) and B15 (7.2\%) frequencies were not increased; (b) B 18 was increased $(30.9 \%$; $p<0.01)$; (c) DR $3(64.9 \% ; p<0.0005)$ and DR $4(51.4 \% ; p<0.0005)$ were also increased; (d) DR $2(10.8 \% ; p>0.05)$ was not significantly decreased; (e) DR5 $(8.1 \% ; p<0.005)$ and DR7 $(16.2 \% ; p<0.005)$ were significantly decreased; (f) BfF1 gene frequency (0.2) was increased $(p<0.001$; normal BfF1 frequency is 0.05 in 330 Spaniards [11]); (g) early onset $<10$ years and DR 4 showed significant association $(p<0.0005)$. BfF1 relative risk $(12.6 ; p<0.0005)$ was similar to DR 3 relative risk $(12.7 ; p<0.0005)$, and $\mathrm{B} 18$ and DR 3 relative risks rose when these antigens were associated to BfF 1 and lowered when they were not (B18-BfF $1: 6.5 ; p<0.05 ; \mathrm{B} 18$-non-BfF1: 1; NS), (DR 3-BfF 1: 19.3; $p<0.0005 ;$ DR 3-non-BfF 1: 2.9 ; NS).

In our Type 2 diabetic sample we found an increase in DR3 $(44.4 \% ; p<0.05)$. Interestingly DR 3 tended to be assoicated by itself (without B 18 and BfF1) in this particular Spanish Type 2 diabetic sample because the relative risks were higher for DR3-non-B18 (8.9; $p<0.01)$ and DR3-non-BfF1 $(7.3 ; p<0.01)$ than for DR3 $(5.2 ; p<$ $0.05)$.

Our results on DR typing in Type 1 diabetes agree with those found by others in Caucasoids $[6,13]$. The significant decrease in DR 5 and DR 7 in our sample supports the view that DR 2, DR 5 and DR 7 are all secondarily decreased in different populations. B 8 and B15 are not increased in our sample because in the Spanish population DR 3 is linked to B 18 and DR 4 is not in linkage dissequilibrium with B 15 [7]. From our previous results [7] and those of this study, we conclude that the haplotype B18-CW 5-BfF 1-DR 3 carries Type 1 diabetic factors in our population and that cross-overs through generations have isolated those factors within the BfF1-DR3 segment.

DR 3-non-BfF1 and non-B 18 was increased in our Type 2 diabetic patients. This may be an indication that this particular DR 3 does not belong to the B18-Cw5-BFF1-DR 3 haplotype or the Type 1 diabetic haplotype. These findings support the view that there may be several closely linked factors or genes within an HLA haplotype, all of which could be necessary for the development of insulin dependence. $A b-$ sence of one or several HLA diabetic factors may lead to the develop- ment of Type 2 diabetes [8]. It may be that in a particular Type 2 diabetic sample one could find an isolated $\mathrm{B} 18$ (non-BfF 1 [8]) relatively raised and in another sample an isolated DR3 (non-BfF1, non-B18) could be found relatively raised (see present data).

Yours sincerely,

M. Serrano-Ríos, J.R. Regueiro, R. Severino, C.López-Larrea and A. Arnaiz-Villena

\section{References}

1. Nerup J, Cathelinean Cr, Seignallet J, Thomsen M (1977) HLA and endocrine disease. In: Dausset J, Svejgaard A (eds) HLA and diseases. Munksgaard, Copenhagen, pp 149-167

2. Batchelor R, Morris PJ (1978) HLA and disease. In: Bodmer WF, Batchelor JR, Bodmer JG, Festenstein H, Morris PJ (eds) Histocompatibility testing 1977. Munksgaard, Copenhagen, pp 205-258

3. Ramm D, Stein R, Alger CA, Gabbay KH (1979) Genetic markers for insulin-dependent diabetes mellitus. Lancet 1: 1208-1210

4. Deschamps I, Lestradet H, Marcelli-Barge H, Benejam H, Busson M, Dausset J (1979) Properdin factor B alleles as markers for insulin-dependent diabetes. Lancet 2: 793

5. Svejgaard A, Platz P, Ryder LP (1981) Eight Workshop Joint Report on insulin-dependent diabetes mellitus. In: Terasaki PI (ed) Histocompatibility testing 1980. University of California, Los Angeles, pp 638-656

6. De Moerloose P, Jeannet M, Bally C, Rafoux C, Pointel JP, Sizonenko $P$ (1978) HLA and DR antigens in insulin dependent diabetes. Br Med J 1: 823-824

7. Arnaiz-Villena A, Rodríguez-Córdoba S, Vela F, Pascual JC, Cerveró J, Bootello A (1981) HLA antigens in a sample of the Spanish population: common features among Spaniards, Basques and Sardinians. Hum Genet 58: 344-348

8. Arnaiz-Villena A, Rodríguez-Córdoba S, Dujovne IL, Regueiro JR, Bootello A, Serrano-Rios M (1980) HLA factors in non-insulin dependent diabetes mellitus. New Engl J Med 303: 1065

9. Mittal K, Mickey MR, Signal DP, Terasaki PI (1969) Serotyping for homotransplantation XVIII. Refinement of microdroplet lymphocyte cytotoxicity test. Transplantation 6: 904-912

10. Gutiérrez C, Bernabé R, Vega J, Kreisler M (1979) Purification of human T and B cells by a discontinuous density gradient of Percoll. J Immunol Methods 29: 57-63

11. Rodríguez-Córdoba S, Bootello A, Arnaiz-Villena A (1981) Bf polymorphism and its relationship with HLA antigens in a sample of the Spanish population: high BfF1 frequencies. Tissue Antigens 17:231-237

12. National Diabetes Data Group (1979) Classification and diagnosis of diabetes mellitus and other categories of glucose intolerance. Diabetes 28: 1030-1057

13. Nerup J, Platz P, Ryder LP, Thomsen M, Svejgaard A (1978) HLA, islet cell antibodies and types of diabetes mellitus. Diabetes $27: 247-250$

Dr. A. Arnaiz-Villena

Inmunología

Centro Especial Ramón y Cajal

Ca. Colmenar Km 9,100

E-Madrid 34

Spain 